\title{
圧迫脳における病理組織学的および酵素組織化学的検討
}

\author{
鈴木 幹男
}

\section{Histopathological and Enzyme-histochemical Changes after Brain Compression}

\author{
Mikio Suzuki \\ Department of Neurosurgery, Hirosaki University, Hirosaki 036
}

\begin{abstract}
Summary
Effects of compression of the brain at various pressures were studied histopathologically and enzyme-histochemically. Sixty two adult mongrel dogs were used under general anesthesia with pentobarbital sodium. After craniotomy, the frontal lobe was compressed for an hour directly by a plastic disc $10 \mathrm{~mm}$ in diameter, which was connected to a spring.
\end{abstract}

(1) Degree of brain damage under various compression pressures. Eighteen dogs were divided into three groups. For each group, the brain was compressed with pressures of $60 \mathrm{mmHg}, 100 \mathrm{mmHg}$ and $240 \mathrm{mmHg}$ respectively. The brains compressed with a $60 \mathrm{mmHg}$ pressure showed vasogenic brain edema histopathologically. Those with a $100 \mathrm{mmHg}$ pressure showed mainly softening and necrosis due to venous infarction and they were dominant in the white matter. The brains compressed with $240 \mathrm{mmHg}$ demonstrated venous infarction and hemorrhagic infarction secondary to pericapillary diapedetic hemorrhage.

(2) Effect of subarachnoid hemorrhage on the compressed brain. In eight dogs, $1 \mathrm{~m} / / \mathrm{kg}$ of autogenous blood was injected into the cisterna magna. Two days later, these dogs underwent brain compression under $240 \mathrm{mmHg}$ of pressure. Histopathologically the brains showed no significant differences compared to the brains without subarachnoid hemorrhage which were compressed with the same pressure.

(3) Effect of cortical vein section on the compressed brain. In $12 \mathrm{dogs}$, bridging veins were sectioned before brain compression with $240 \mathrm{mmHg}$ of pressurc. Five of them showed macroscopic hematomas predominant in the white matter. Seven of them showed microscopic hemorrhage. In another five dogs, bridging veins were sectioned but compression was not performed. Two of them showed only scattercd pericapillary hemorrhage without hematoma or infarction. The rest showed neither edema, infarction nor hemorrhage. These data demonstrated that disturbance of the venous return aggravated the degrce of brain damage by brain compression, and suggested that bridging veins should be preserved whenever possible during any operation.

(4) Enzyme-histochemical changes were investigated with phosphorylasc (P-Pase), glucose-6-phosphate dehydrogenase (G6PD), lactate dehydrogenase (I,DH), alkaline phosphatase (Al-Pase), adenosine triphosphatase (ATPase) and cytochrome oxidase (Cyt, ox.). The infarcted area showed decreased activities of all these enzymes except LDH in some cases. Edematous and peri-infarctic areas demonstrated increased activities of P-Pase, G6PD and LDH in the astroglial cells, and increased Al-Pase in the capillary walls, but decreased activities of ATPasc and Cyt. ox. in the astroglial cells. These enzyme-histochemical findings indicated increased acrobic glycolysis, disturbed metabolism in the mitochondria, and permeability changes in the astroglial cells and the capillary walls, mainly due to the impaired blood-brain barrier.

(5) Effects of therapeutic agents were investigated by the enzyme-histochemical technique in 19 dogs. Ten percent glycerol $(5 \mathrm{~m} / \mathrm{kg} /$ day i.v.) reduced the activity of G6PD and increased the activity of LDH and ATPase.

弘前大学脳神経外科

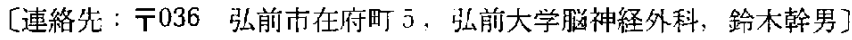

1980年4月4日 受稿 
Glycerol seemed to be utilized to preserve enzyme activity and energy metabolism. Dexamethazone $(2 \mathrm{mg} / \mathrm{kg} / \mathrm{day}$ i.m.) increased the activity of LDH which could accelerate the glycolysis. Therefore it had the effect of improving the metabolism. Dimethyl sulfoxide (DMSO, $4 \mathrm{ml} / \mathrm{kg} /$ day i.v.) had no effect on the compressed brain. Histopathologically, however, these three agents had no effect on the infarcted brain.

\section{Key words: brain compression, brain injury, enzyme-histochemistry, cerebral vein}

\section{I はじに}

脳組織に圧迫が加わることによって引き起こされる脳 損傷には, 臨床上経驗する外傷, 頭蓋内新生物や血腫な どによる脳内外加らの圧迫に上るものや，開頭手術中に 術者がやむ学えず行う脱表よりの脳圧排によるものなど がある. 前 3 者の頼蓋内占有物によるものは頭蓋内圧方 進を毛伴い, また, 従来の脳圧迫による実験的脑損傷の 作製法洼，硬膜外バルーン法614)34)，異物の脳内埋没法 や頭蓋内人の血液等の注入法などがあるがあ(34)39347)，これ らの方法はいずれも閉鎖された頭蒀内で作製され，頭蓋 内圧光進む伴い，脳全体に頭蓋内圧光進の影響が及び， 圧迫部の組織変化は必ずしも圧迫自体によるものとは限 らない，脳手術に敌いて，時に経験する脳圧排によって 生ずる局所の脳租織損伤の病態と, 先に述べた頭蓋内占 有物が局所の組織に与える变化を観察する日的には，頭 蓋内圧が開放された条件下での圧迫が必要と思われる。

また，開頭手術において，時に視野の確保などの目的で 静脈の切断が必要とされる場合や，クモ膜下出血などの 条件が加わった脳に対し圧排が行われ，時に重篤な結果 を招く場合があるが，静脈還流障害やクモ膜下出血と脑 圧迫との関連についての検索は，従来ほとんどなされて

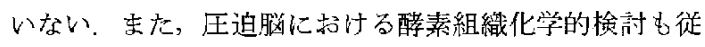
来ほとんどなされていない，

頭蓋内圧開放下で脳圧迫による局所の脳組織の変化 と, 静脈還流障害やクモ膜下出血などの因子が加わった 場合の影響について検索するた好に，本研究ではイヌの 頭蓋骨空上り合成樹脂円板に上り一定時間压迫在行い， 病理組織学扔上び酔素組織化学的に検討した。

\section{II 実験材料と方法}

\section{1. 脳圧迫および材料の採取}

笑験に法体重5.6 12.3kg, 平均7.6kgの雑種成犬 62 頭 を用いた。 ペントバルビタールナトリウム(ネンブター ル) $25 \sim 30 \mathrm{mg} / \mathrm{kg}$ の静脈内投与に上る全身麻酸のもと に気管内插管し，一側開頭を行い，脳表を脑外科用綿片 で覆い，直径 $10 \mathrm{~mm} の$ 合成樹脂円板でば材化上り 1 時 閻にわたり脳に圧迫を加えた，単植誘導による脳波記録 を行い，压迎解除後 silastic 製の人工硬膜齐用いてア口 ンアルファ (aron alpha cyanoacrylate系接着鼡)にて肯
㥶を閉じ，脑表への血液や筋組織などの影響を避けた， 創を閉し，抗生物質（セファロリジン50 mg/ $\mathrm{kg}$ ）筋肉 内投与し，2３日間生存後全身麻醉下に大腿動脈切断 または大腿動脈より心臟側へカテーテルを挿入し，急速 に脱血死させ速やかに媨摘出し組織の検索に供した。 圧迫脳組織に书许る色素の血管外漏出の有無を観察する ために, $25 \%$ Evans blue $1 \mathrm{~m} l / \mathrm{kg}$ を脱血15分前に静脈内 投与した.

\section{2. 実験群の種別}

脳外科臨床において遭遇する諸条件を次の各群によっ て模式化して比較检討を進めた。

1) 圧迫力と脳損稘の程度との相関を調べる目的で, 18 頭在 6 頭ずつ 3 群に分外，それぞれに60，100，240 $\mathrm{mmHg}$ の压迫力を加えた.

2）クモ膜下出血が圧迫脳记対して与える影響につい て検索するために，8頭には圧迫に先立ち，全身麻醉後 大腿動脈より採取した自家血 $1 \mathrm{~m} / / \mathrm{kg}$ 直ちに大槽内に 注入乙，人工的クモ膜下出血犬（SAH 犬）作製し， 2 日後に240 mmHg の压迫を 1 時間加之た.

3）静脈還流障害の影響を調べる目的で，12頭に対し て,開頭後 dorsal sagittal sinus に入る部分すなわち橋静 脈党焼昫切断乞，その後に2 $40 \mathrm{mmHg}$ の圧迫を加えた。 また，静脈還流障害のみの影響を調べるために５頭に ついては橋静脈の切断のみを行い压迫を加えなかった。

4) 薬剤の圧迫脳に対する影響を調べる目的で，19頭 の) $240 \mathrm{mmHg}$ 压迫犬为 7 頭, 6 顽, 6 頭の 3 群记分け, (1)デキサタサゾン $2 \mathrm{mg} / \mathrm{kg} /$ day 在術前に静脈内投与し, 手術翌日上り筋肉内に同量投与, (2) $10 \%$ ダリセロール (CGA 30) $5 \mathrm{ml} / \mathrm{kg} /$ day 在压迫後上り点滴静注， (3)50\% dimethylsulfoxide (以下 DMSO 上略称寸る) を压迫直後 より点滴静注した.

いずれのイヌも $2 \sim 3$ 日間生存後汇前述の方法で屠殺 Lt.

\section{3. 病理組織学的検索法}

摘出脳住血液や生食などの付着を避付, 可及的速やか に圧迫部と云の周辺の正常組織在含むよう，また，非圧 迫侧の灰白質上白質在含めて約 $10 \mathrm{~mm} \times 10 \mathrm{~mm}$ のきき で厚さ $5 \mathrm{~mm}$ 程度の切片を切り出し，一部は酵素組織化 学的検索用とし，残りの媨は $10 \%$ ホルマリン固定を行 い，小標本と前額断面の大型標本作製に供した。 ホルマ 


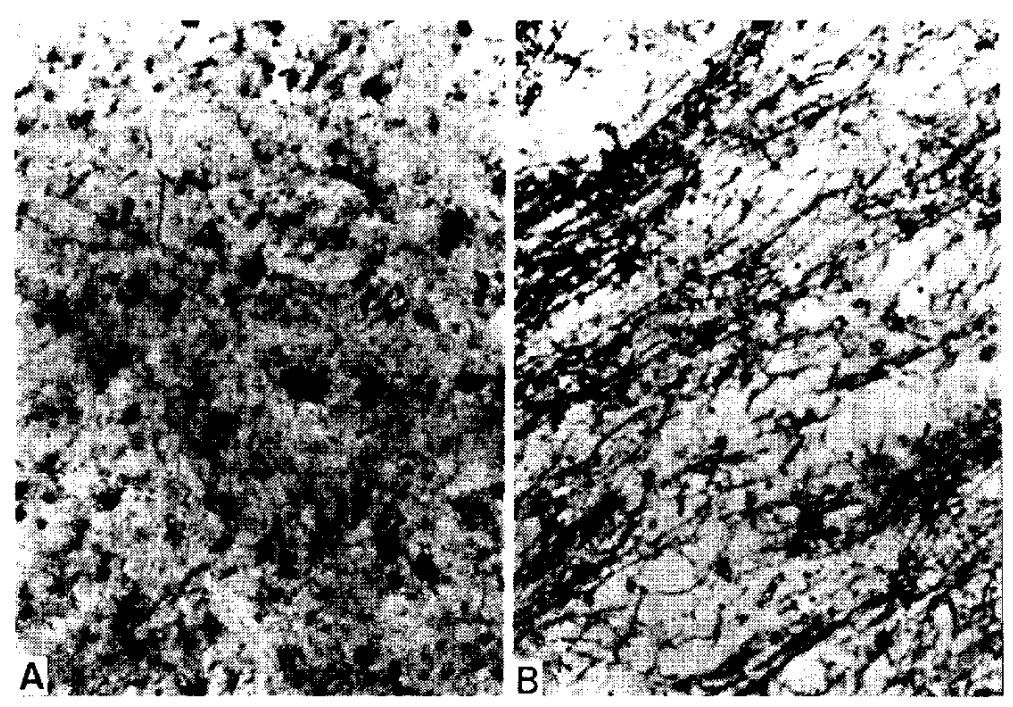

Fig. 1 Histology of a $60 \mathrm{mmHg}$ compressed brain.

A: Reactive gliosis in the compressed cortex. FAN $\times 200$

B: "Spongy appearance" in the white matter. Fragmentation of the myelin is present in this spongy area. KB $\times 200$

リン固定標本はパラフィン包埋し, hematoxylin eosin法 (以下 HE 法と略称す), Klüver Barrera法 (以下K B 法 と略称す), Holmes 法, Holzer 法の各染色䘮行い光学 顕微鏡下に検討を加えた。

\section{4. 酵素組織化学的検索法}

切り出された未固定の切片のうち，1倜は $4{ }^{\circ} \mathrm{C} の$ formol calcium に18 24時間固定後, 泠尞溜水で30分水洗 t回行い, gum acasia mixture (sucrose $300 \mathrm{gr}+\mathrm{gum}$ acasia $10 \mathrm{gr}$ 十蒸溜水 $1,000 \mathrm{~m} l$ ) に24時間以上浸漬する. 次に30分間蒸溜水に浸漬した後に凍結切片上する.

末固定の別の切片と, formol calcium にて固定さ扎た 切片を，ドライアイス添加アセトンに浸漬されて邻さ れている銅製 cup内のドライアイス添加イソペンタンで 凍結切片とする， $-20^{\circ} \mathrm{C} の$ クオスタット内 $12 \mu$ の薄切 切片作製し可及的速やかに，formol calcium 固定切片 任 adenosine tri-phosphatase $の$ 染色に, 新鮮凍結切片は それ以外の酵素染色に供した。酵素染色は，糖代謝生た は血液譄関門と関連すると考它られる以下の6 種につい て行った。これらの方法を列記するが，処方や染色手順 等については省略寸る。

(1) Glycogen phosphorylase (以下 PPase と略称才) : Takeuchi and Kuriaki 法 ${ }^{423}$. (2) Glucose-6-phosphate dehydrogenase (以下 G6PD と略称与) : Nitro-BTに よる tetrazolium 法 $^{25)}$. (3) Lactate dehydrogenase (以 下 LDH と略称す) : Nitro-BTに上る tetrazolium 法 ${ }^{25}$. (4) Cytochrome oxidase (以下 Cyt. ox. と略称
才) : Burstone 法 $^{3}$. (5) Adenosine tri-phosphatasc (以 下 ATPase 上略称す) : Wachstein and Meisel 法 ${ }^{46)}$.

(6) Alkaline phosphatase (以下 Al-Pase 上略称す) : Burstone 法".

な拉，以上いずれに拀いてす incubationの際は常に非 圧迫側の脳の切片も行い対照とし, また，醉索活性部位 の同定のため, HE 法と FAN 法を同一凍結切片で行い， 光学顕微鏡下で検封索加えた。

\section{III実験結果}

\section{1. 压迫力の強弱による差異}

$60 \mathrm{mmHg}$ 压迫群の媨表江压迫部に一致して膨隆して 軟かく，Evans blue 注入後の㓶面で活，圧迫部の白質に lake 状の色素の漏出が肉哏的に観察され，灰白質に浔認 わられなかった，光顕では，FAN 法で星状膠細胞の增 加と胞体の膨化がみられ reactive gliosis の像を呈し， KB 法で噵鞘の断裂と間隙の開大 “spongy appearance”

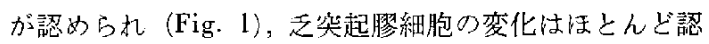
から扎なかった，以上の所茪より $60 \mathrm{mmHg}$ 群は単純な 譄浮腫の状態と思われる。

$100 \mathrm{mmHg}$ 群では, 压迫部の害面で白質の軟化が触知 され，光顕では好中球および貪食細胞が混在して海綿状 構造をなし，周囲の組織には reactive gliosis がみられ た。これらの所見は必白質にもみられるが，白質に上り 著明で皮質下の白質に限局している場合もある，硬塞像 と考えられる (Fig. 2). 硬塞巣の周囲の組織では，血管 


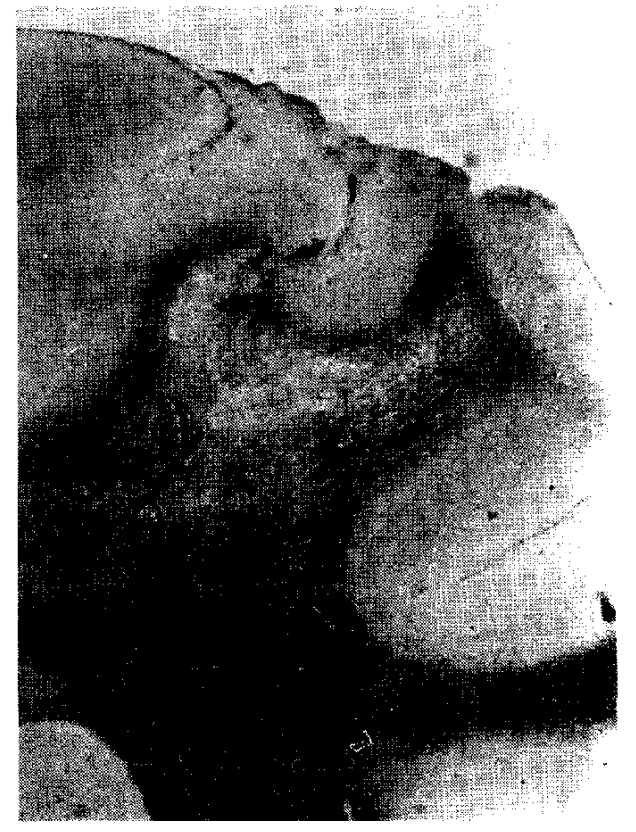

Fig. 2 Histology of a $100 \mathrm{mmHg}$ compressed brain. Infarction is shown in the subcortical white matter. $\mathrm{KB} \times \mathrm{I}$

腔内に赤血球がうっ滞し，一部血管外一漏出している像 も散晃された。

$240 \mathrm{mmHg}$ 圧迫群では100 mmHg圧迫群の所見に加え て，毛細血管上りの漏出と思われる多数の小出血樂が特 徵的であった，出血は灰白質より白質に著明であった が，血腫は形成されず硬塞㮍の周囲には浮腫像が認めら れた。

\section{2. 橋静脈切断またはクモ膜下出血に対する圧迫の影 \\ 響}

対照として正迫を加えず橋静脈切断のみを行った 5 頭 のちち，2頭の脳は開頭密に沿って腫大していたが，肉 眼で Evans blue の漏出はみられず, 光顕で悠白質と白質 の血管内の赤血球ら口㴖と，毛細血管周囲の漏出が観察 されたが，硬塞像や髄鞘の変化はほ上んどみられなか。 た. 他の3頭の㨫は肉眼的にも光䫓にても血管腔内の赤 血球うっ滞以外特記寸べき所見は得られなかった。

橋静脈を切断した後に $240 \mathrm{mmHg}$ の压迫を加えた 12 頭については，5頭に血腫が形成された(Fig. 3，4)。血 嗹は白質老中心に広がり，大きさは最大直径 $6 \mathrm{~mm}$ から $25 \mathrm{~mm}$ と種々で女ったが，このよ5な血腫形成は，橋静 脈切断のみの群抢上び死迫のみの群にはみられなかった ものである，大血腫形成した例では，血腫は压迫侧の

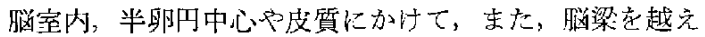

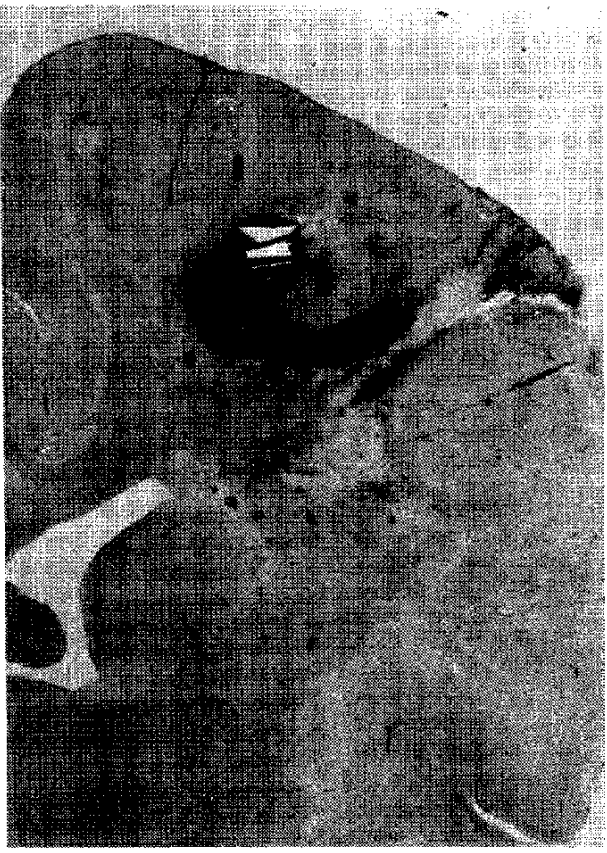

Fig. 3 A $240 \mathrm{mmHg}$ compressed brain after cutting of the bridging veins shows hematoma localized in the white matter and perivascular hemorrhage predominant in the white matter. $\mathrm{HE} \times \mathrm{I}$

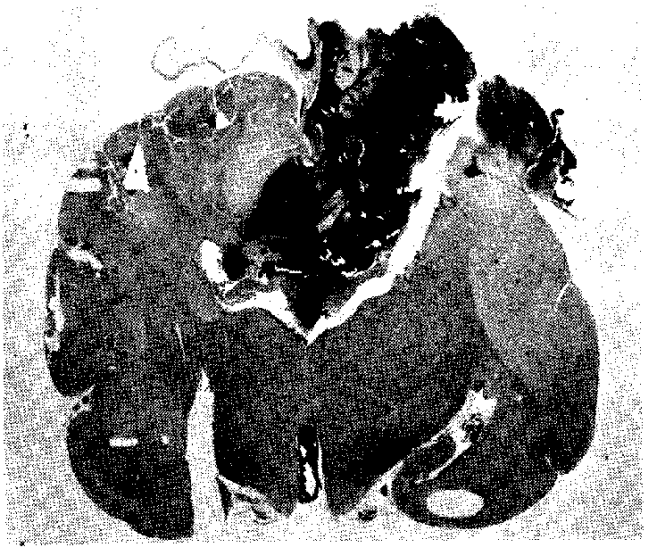

Fig. 4 A slice of $240 \mathrm{mmHg}$ compressed brain aftcr cutting of the bridging veins shows a massive hematoma due to infarctic hemorrhage. Brain tissue is still observed in the hematoma. $\mathrm{HE} \times 1$

て対側の帯状回から脳室人穿破していた (Fig. 4). 血腫 塊の中に注脳組織が含屯れ硬塞性出血の像を呈している (Fig. 4). 周囲の白質には浮腫と小出血像がみられた。

SAH 犬に压迫を加えた媨では，白質に僋勢な硬塞巣と 周囲の小出血巣がみられ，非 $\mathrm{SAH}$ 圧迫犬との閒に差異 


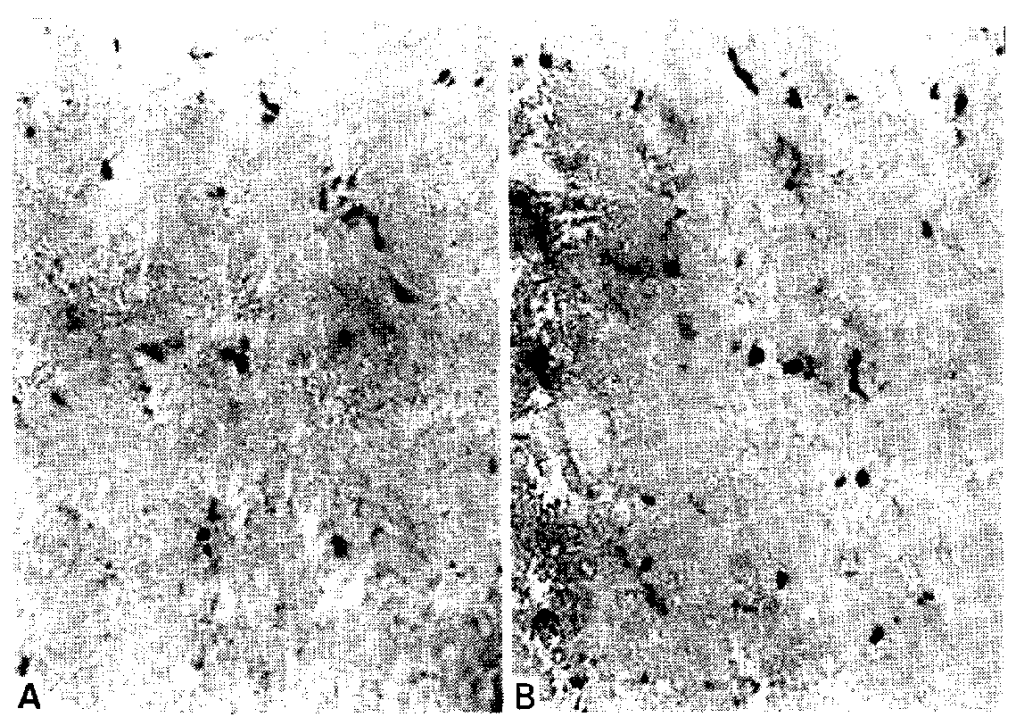

Fig. 5 Phosphorylase

A: Control white matter.

B: Incrcased activity in astrocytes in the compressed white matter.

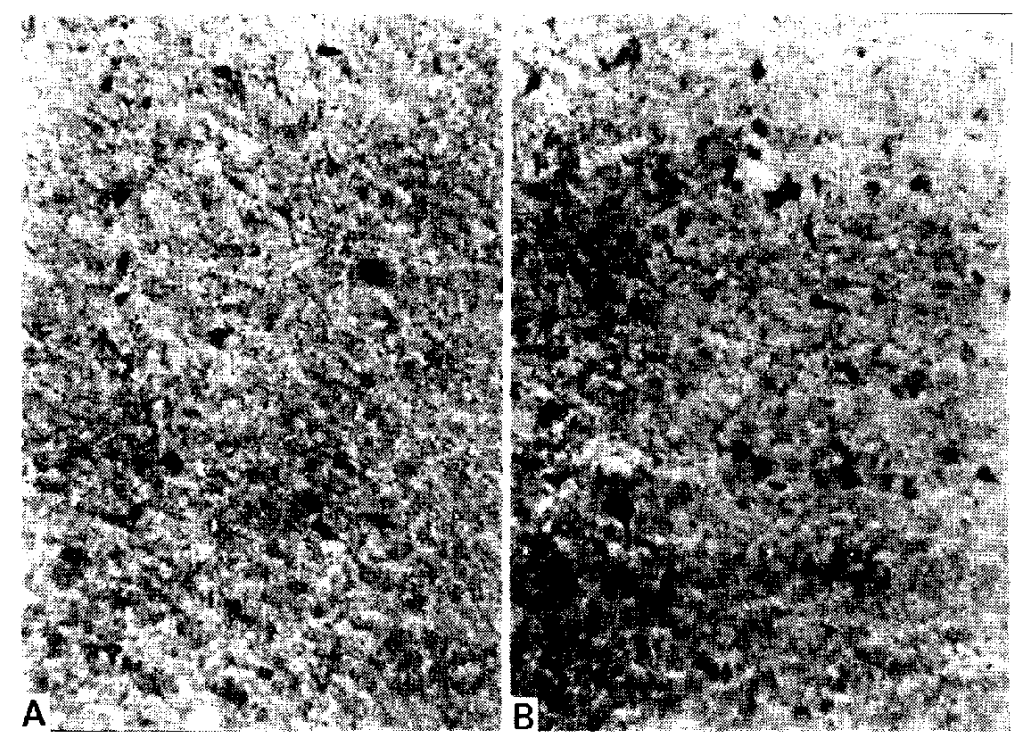

Fig. 6 Lactate dehydrogemase

A: Control grey matter.

B: Increased activity in enlarged astrocytes in the compressed grey matter.

文認めなかった

\section{3. 酵素組織化学的検討}

PPase 汢, 正常朕の白質の星状膠細胞に活性がみら れ，圧迫脳の浮腫部で活性の増加がみられた（Fig. 5)， $100 \mathrm{mmHg}$ 以上扝よび $\mathrm{SAH}$ 後の压迫腷で硬塞坚の活性 は著しく低下したが，硬塞周囲の組織の活性は増加し た.
G6PD は，神経細胞で轻度の星状膠細胞で微かに活性 を示し，压迫檤では浮腫組織㧍上び硬塞周囲組織におい て星状膠細胞の活性增加が㓋察された。硬塞巣内では， 島状に活性増加を示す部分もあったが，他の部位では活 性は低下していた，压迫の強さによる差異は認めなかっ た。

LDH は正常䐉では神経細胞，星状膠細胞や之突起膠 


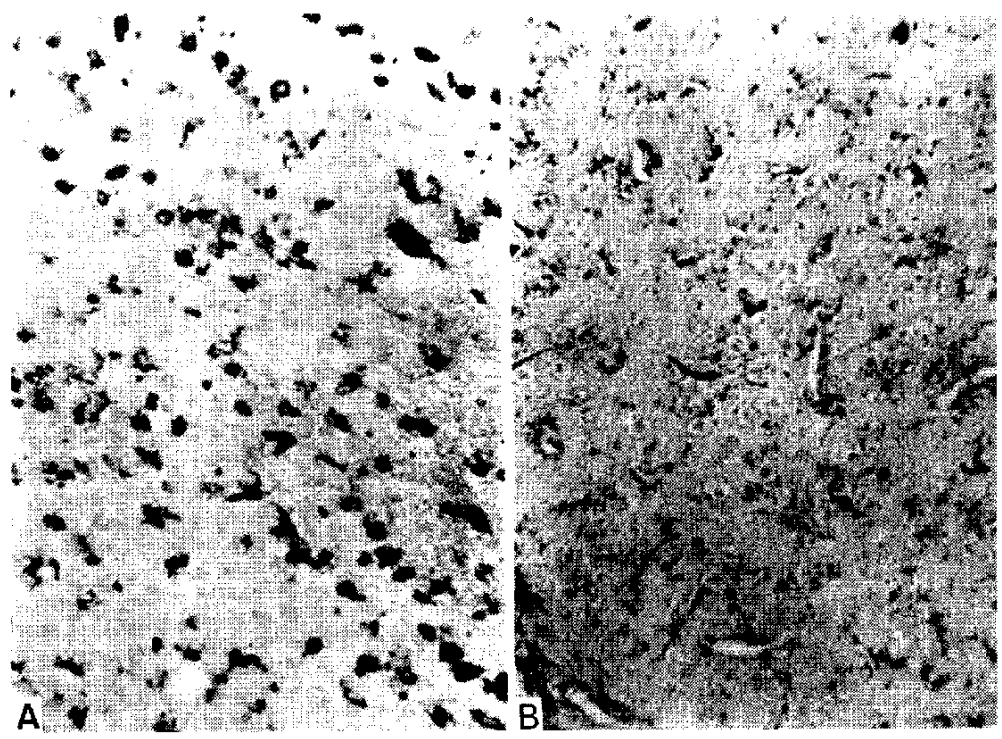

Fig. 7 Cytochrome oxidase

A: Control grey matter

B: Decreased activity in enlarged astrocytes in the compresscd grey matter.

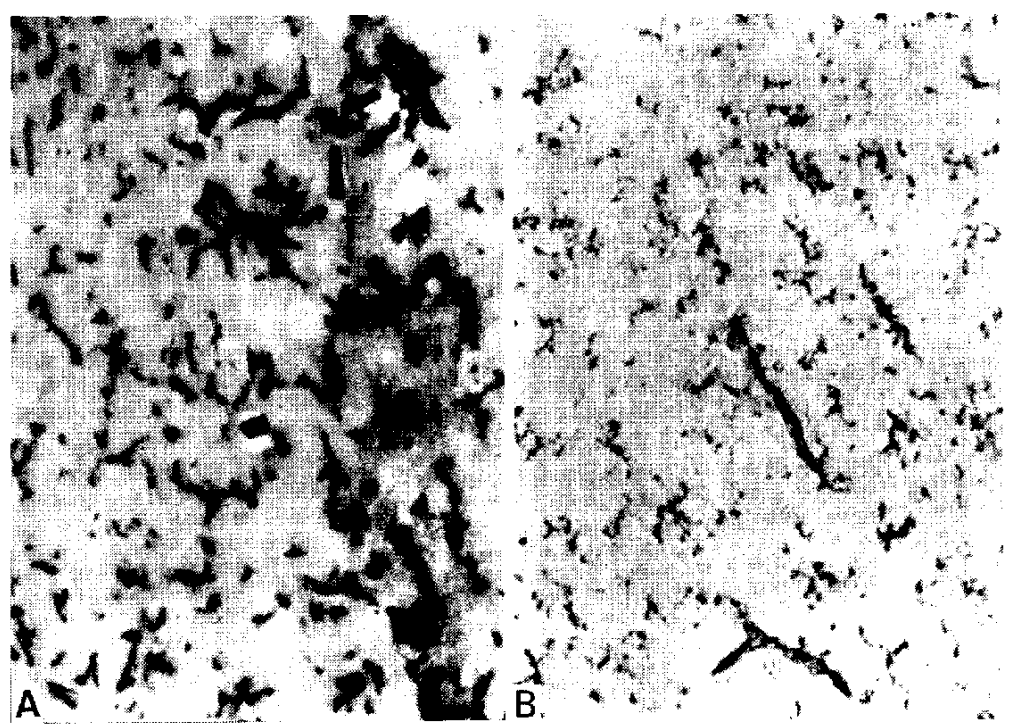

Fig. 8 Adenosine triphosphatase

A: Control gray mattcr.

B: Decreased activity in enlarged astrocytes in the compressed gray matter.

細胞の細胞体に主として活性がみられ，正迫脳の浮腫部 や硬塞单の周囲の組織に扔いて星状膠細胞の活性増加が みられた (Fig. 6).

Cyt. ox. は正常脳では灰白質に活性が強く白質に弱 い. 神経細胞はほとんど活性を示さず，星状膠細胞の特 に細胞質の辺縁に強い活性がみらられるが（Fig. 7)，圧迫 脑の星状噖細胞の活性は減少した。
ATPase は神経細胞の活性はほとんど示さず，星状䏧 細胞の細胞質，突起および毛細血管壁に活性がみられ， 压迫譄に招いて浮腫部の星状膠細胞の活性低下がみられ たが，毛細血管壁の活性注不変，硬塞巣ではいず扎も活 性を示さなかっ (Fig. 8).

Al-Pase は正常脳の毛細血管壁に一様な活性がみら れ，神経細胞や膠細胞には活性が示されなかった。毛細 


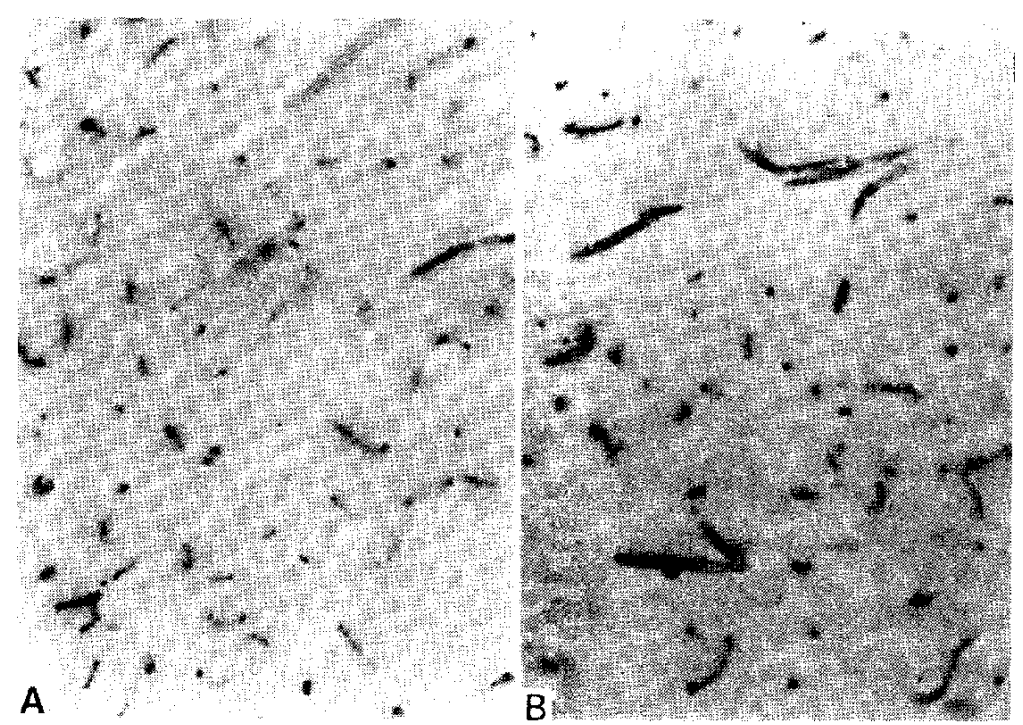

Fig. 9 Alkaline phosphatase

A: Control white matter.

B: Increased activity in the capillary wall in the compressed white matter.

Table 1 Changes in enzyme activity (1)

\begin{tabular}{|c|c|c|c|c|c|c|c|}
\hline \multirow[b]{2}{*}{ Pressure } & & & \multirow[b]{2}{*}{ Cyt.ox. } & \\
\hline & Histology & PPase & G6PD & $\mathrm{LDH}$ & & ATPasc & Al-Pase \\
\hline Control & normal & +++ & $\therefore$ & - & ++- & $+-\nmid$ & ++ \\
\hline $60 \mathrm{mmHg}$ & edcma & |. $-+\sim++\perp+$ & -+ & -+ & ++ & $f++$ & +++ \\
\hline $100 \mathrm{mmHg}$ & infarction & $\mid++\sim++--$ & $-\perp$ & -+ & $1+1$ & $\dot{+}-$ & +++ \\
\hline $\begin{array}{c}240 \mathrm{mmHg} \\
\mathrm{SAH}+\end{array}$ & $\begin{array}{l}\text { hemorragic } \\
\text { infarction }\end{array}$ & $--\quad++$ & $\dot{-}+$ & ++ & ++ & -1 & +++ \\
\hline $240 \mathrm{mmHg}$ & hematoma & -++ & $\dot{+}+$ & $1-\sim++$ & ++ & $\dot{-}$ & +++ \\
\hline
\end{tabular}

血管壁の活性は，圧迫による浮腫部でぞの活性の鲑加が 観察された（Fig-9).

以上の上らに，正常檤の酵素活性は膠細胞，特に星状 膠細胞に活性が高い場合が多く，医追により Al-Pase 毛細血管壁で，その他の酵素では主に星状膠細胞に掠い て活性の変化が観察された，各圧泊力および $\mathrm{SAH}$ 後の 圧迫に抒ける酵菒活性変化在 Table 1 に要約した。

\section{4. 薬浏投与による影響}

デキサメサゾン，グリセロール抢よび DMSO 投与例 では，以ずれも組織学的には硬塞像を示し，非投与群と の閒に差異在認めなかったが，酵素組織化学的に注 Table 2 に示すよらに，デキサメサジンでは LDH の増 加，グリセロールでは G6PD の低下とLDHと ATPase の増加がみられた。 DMSOの投与例では差異を認わら れなかった。

\section{IV 考察}

\section{1. 圧迫脳における病理組織学的検討}

実験的に脳に圧追索加えることに上り脳損傷を発生せ しわる方法としては，脳出血在想定した方法以外では硬 膜外バルーン法(6)1433，頭蓋内に異物党埋没する方 法3439947等があるが，いずれる頭蓋内圧六進発現せし め，庄迫部位のみならず，脸全体にその影響を及ほする のである，脳手術において脳を圧排する際泣，頭蓋内压 が開放された状態にある。したぶって開頭下に媨表を圧 迫寸る方法は，脳の局所に対する圧迫に上る組織の变化 をとらえるのに有效な方法といえる。

圧迫力上㨫組織の病理組織学的変化性， $60 \mathrm{mmHg}$ で 脳浮腫, $100 \mathrm{mmHg}$ 越えると出血性硬塞がみられる。 Albin ら 
Table 2 Changes in enzyme activity (2)

\begin{tabular}{|c|c|c|c|c|c|c|}
\hline $\begin{array}{l}\text { Pressure } \\
240 \mathrm{mmHg} \& \\
\text { treatment }\end{array}$ & PPase & $\mathrm{G} 6 \mathrm{PD}$ & $\mathbf{L D H}$ & Cyt. ox. & ATPase & Al-Pase \\
\hline Control & $+t-$ & + & + & +++ & +++ & ++ \\
\hline Lesion & $++:+$ & ++ & ++ & ++ & + & +++ \\
\hline Dexamethazone & $++1+$ & ++ & +++ & ++ & + & $++t$ \\
\hline Glyccrol & $+\div+t$ & $+\sim \div+$ & +++ & ++ & $+\sim++$ & +++ \\
\hline DMSO & +-++ & $+\perp$ & ++ & ++ & + & +++ \\
\hline
\end{tabular}

+- mild, +- moderate, +++ strong, +++- very strong

時間加え，72時間後の検索では retractor の圧が $20 \mathrm{mmHg}$ 以上で体感覚性誘発電位り測定で autoregulation が低下 し, $30 \mathrm{mmHg}$ で腷浮腫が発生し，40〜50 mmHgr越え ると硬塞を生しるとしている。本生験の艮迫力の程度と 組織像しの相関と比較して，圧迫力の違いがあるが，そ れはばね力を利用しているために，譄に加わる压が压迫 当初上終期では異なるためと考えられる，しかし，臨床 的に retractor による脳圧排仕当初強以压が折わるのが 常であり，より臨床に近い生迫法といえよう。

圧追によって生ずる脑浮腫は，色素の漏出が白質に優 勢であること，後述するように酵素組織化学则に毛細血 管壁の透過性の障害が示唆されることなどれら，Klazo が分類したところの vasogenic edemaに属するものと思 われる。

正迫力が100 mmHg を越えると生ずる硬塞と，240 $\mathrm{mmHg}$ でみられた出血性硬塞像は白質に優莂で, 血管周囲 漏出性出血む白質に著明で女る。㮸の micro-circulation 恃表在静脈一流出寸る pial vessels と, 深部一流出し大 大脳静脈人集合する transcerebral vesscls があり，届者は 皮質下の白質にその源圭発する ${ }^{132}$.この2つの静脈逗流 系に吻合静脈が存在するにしても ${ }^{10)}$ ，压迫力により灌流 圧の低い静脈が選択的に循環障害を生じ, 解剖学的に灰 白質に比べ血管床の小さな白質が，しかも表在静脈一流 出寸る pial vessels と transcerebral vessels の接点である 皮質下の白質が，压迫に対してもっとも易損性をもつむ のと芳えられる。

動脈性硬塞洨，灰白質の酸素需要が白質に比べて 5 倍 多くそのために灰白質の毛細血管の内皮紐胞が損稘孛 受けやすく，毛細血管周囲の出血が灰白質に主にみられ る383のに対し，静脈性硬塞では灰白質に比ぶて白質に出 血傾向が強いとされる ${ }^{493502}$ 。したがって，圧迫脳で生 しる硬塞は静脈性硬塞といえる. 静脈性の硬塞性出血の 病因について注不詳とされている 血の発生機序は，頭蓋内圧穴進による高血圧，組織の高 $\mathrm{CO}_{2}$ 症による血管桩張，局所の血管壊死による血管破

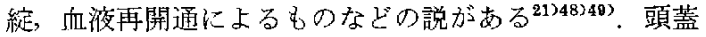
内圧穴進時の脳幹部の組織変化の研究では, 頭蓋内圧が $700 \sim 800 \mathrm{mmH}_{2} \mathrm{O}(51.5 \sim 58.0 \mathrm{mmHg})$ で血管内への 赤血球りらっ滞, $1,000 \mathrm{mmH}_{2} \mathrm{O}(73.55 \mathrm{~mm} \mathrm{Hg})$ で径 $20 \mu$ 以下の血管よりなる microcirculation hemorrhage, $1,100 \mathrm{mmH}_{2} \mathrm{O}(80.90 \mathrm{mmHg})$ 以上で200 $\mu$ 以上の血管 よりなる macrocirculation hemorrhage がみら扎るよう になるとされている゙。 限勾性圧迫で $100 \mathrm{mmHg}$ で血 管内の赤血球らっ滞と毛細血管周囲の漏出性出血吕一部 に文られ，240 mmHg では小出血仿著明であった結果 と，組織学所見はほほ類似しているむのと思われる。脳 幹部 $の$ macrocirculation hernorrhage $の$ 原因江組織の distortion と推論されているがの゙, 頭蓋内圧元進が㹸幹部 へ加わる压のメ力二ズムから納得し5るものである。本 奏験は厈迫が解除されており，機械的歪の影響上りも， 死迫による语環障害のため局所の anoxia が生し，血管 の透過性が立進寸ることと圧迫解除による血管の一部が 再開通することが関連しているものと思われる。

監休的静脈還流障害は上失状洞扎拴に上るものがす 上も多く, 表在静脈-や他の静脈洞や媣部静脈洞血栓がこ れに統くとされる ${ }^{40)}$. 実験的にも上矢状洞血栓が古くか ら注目されている33. 開頭術の際に視野を確保するため にやさをえず橋静脈を切断する場合があるが，橋静脈切 断自体の脳組織に対寸る影響や，他の因子が加わった場 合にはき起こされる脳組織の損傷については必ずしも明 らか比されていない，イヌでは，橋静脈切断のみ在行っ た脳では全例肉眼では著変みられず，光顕で血管腔の拡 大と赤血球のらっ滞が，一部の脳の日質に小出血がみら れたが硬塞の所見は認めない，臨床例のよらな上矢状洞 血栓に拉いてみられる浮腫や硬塞の所見がみられないこ とは興味樑い.

橋静脈切断後に圧迫老行った揚合に, 非切断群では婄 められなかった血腫が形成されたことは，静脈還流障害 が庄迫媨に対し重篤な障害をもたらすことを示唆する。 臨床的にも，老人脳の橋静脈切断と脳圧排に上り璃内血 
腫が形成される場合があるとして，橋静脈切断を敩にい ましめている報皆もある゙1。橋静脈切断単独群と区迫単 独群の腷に共通する病理組織所見は, 血管腔内の赤血球 らっ滞と血管周囲漏出性出血である，两因子が相加的飞 脳に損賃を与元，血管譬の透過性の㜔害と，圧迫解除に より血管の再開通が起こり，压迫解除後に壊死果内に出 血し血腫が形成されるものと思われる。

クモ膜下出血〈SAH）が压迫細に与える影響を検討す るために，実験的 SAH 犬に圧迫至加えた㨫の病理組織 所見㤝，非 SAH 犬と有意の恙を認好なかった。臨床的 に SAH 発症後の媨循環任低下し, 脳循環 lationの裚失も起こるとされる ${ }^{41}$. そこ一圧迫による循 環障害が加わった場合, さらに重篤な損傷を生じること が推測されたが，病理組織学的にも醇素組織化学的にも 有意差が認められなかった。 今後さらに㛟討を要するむ のと思われる。

\section{2. 圧迫㮸における醳素組織化学的検討}

脳組穖が高い醉素消費を示し醳素の欠乏に対し特に敏 感で，血液循環によるブドウ糖と酸素の供給が脳の機能 のために不可欠であることは明らかである ${ }^{132}$. 脳の機能 神経細胞とその突起，才なわちニウロンの連鎖に基つ くもので，酸化代謝に括いて子膠細胞は大きな部分を占 めて扔らす゚，神経細胞は皮質の膠細胞上り平均 $16 \sim 50$ 倍 の呼吸活性を示しているとされている12，しかしなが ら脳組織の大部分点占めるの性翏細胞であり, 腷全体と しては括よそ10対 1 以上の割合で膠細胞の数の方が多い

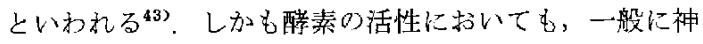
経細胞のエネルギー生成酵素の活性注脳全体の平均上り も低く，特に解精采に扔いては，灰白質の他の構成成分 に比べてほとんどの䤃素が明らか儿低く, 神経細胞は余 り関与していないだろらとされている24)。たと洁前角 細胞に㧍计る測定では，LDH および G6PD 法脳組織全 体の半分以下とされている24). 星状膠細胞は毛細血管と 神経細胞間に介在し，養分は星状膠細胞の細胞体を通し て神経細胞一伝達されると考光られており，膠絓胞特に 星状㑩細胞の代謝は, 神経組織の中で重要な役割を担っ ていることは多くの支持をうけている25332).

圧迫脳において硬塞巣では注とんどの醉素活性が低下 し，周囲の浮腫部の活性の増加がみられる，特にLDH の活性分布は好気的代謝学営屯酵素の分布と類似し，好 気的代謝との関連もあるとされるが，大部分においては 嫌気的代謝の盛九な部位に強い活性在示し，嫌気的代謝 の重要な役割を担っている27). 压迫に上り局所の循環障 害のた为汇組織の醉素欠乏が生じ，Cyt，ox．の活性低下 に示されるように,ミトコンドリアの機能障害 ${ }^{15222}$ のた

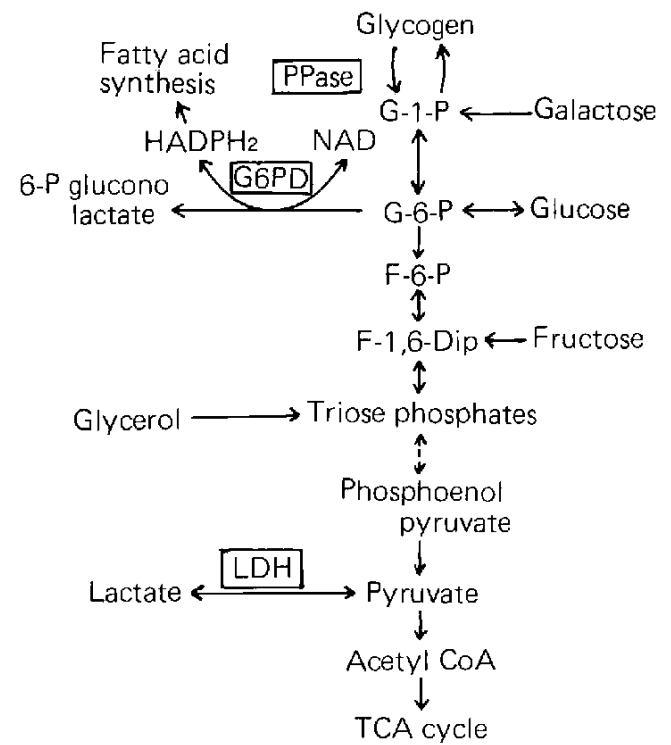

Fig. 10 Glycolysis and certain enzymes.

めエネルギー捕捉が障害され，そ扎に対する反忘として 嫌気的解糖が直進するものと考えられる。

ATPase については, 浮腫組織上正常組織の境界で活

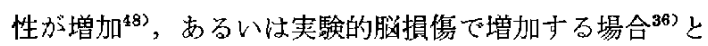
低下与る場合とがある゙5. ATPase はミトニンドリアの

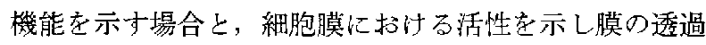
性上関連があるとされる場合があるが351483，今回の方法

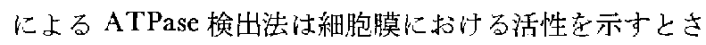
$れ^{463}$ ，血液脳関門で電要な意味をるつとされる ${ }^{297433}$ 星状 膠細胞と毛細血管垶である内皮細胞と基庭膜の障害を示 唆している。

毛細血管壁に抬ける Al-Pase の役割俚血管壁の透過

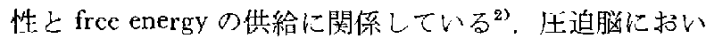
て血管壁の活性增加をみたが，これまでの報告では活性 增加する場合と ${ }^{53}$ 低下す吕場合 ${ }^{16) 222}$ とがあり, 議論の分 かれるとこるである。、以ずれにせよ血管壁の代謝異常を 示するのと思われる。

\section{3. 圧迫脑における薬剂の効果}

圧迫絪に対寸るデキサメサゾン，グリセロール枕よ゙゙ DMSO の效果妾検討したところ，病理組織学的にはい ナ゙れも压迫部の出血性硬塞像を主所見とし，非投与群と の間に差異を認めない，酵素組織学的にはデキサメサゾ ンとグリセロールに差買が諗められた。

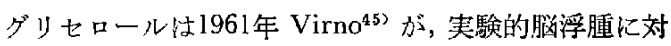
し静脈内投与が優れた効果のあることを報告して以来，

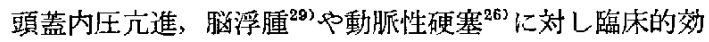
果のあることが認められている，脳組織が高い酸素消費 
を示し，それによって消費される基質はもつぱらブドウ 糖であって，ブドウ糖以外に血液から檤内に取り込生れ ることが確実に証明されている物質はないとされていた が44), Geiger らの ${ }^{14} \mathrm{C}$-glucose 圭用いた研究により，生 成された非放射性 $\mathrm{CO}_{2}$ の主な源泉の 1 つにグリセロー ルがあるといらことが明らかになった。 グリセロール投 与による $\mathrm{LDH}$ 活性増加は，グリセロールが脳内で代愔 され，基質としてのピルビン酸が増加することと（Fig. 10)，グリセロールの酵素活性保持作用によるものと思わ れる，グリセロール核浮腫に対しては高漫透压効果が あげられるが，必ずしもそれだけでは説明しえず2930”， その腷内に打ける詳䋱な代謝についてはいまだ明らかに

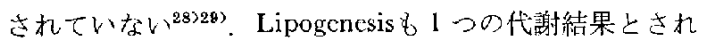
ているが28)29，LDH 拉よび ATPase の増加上り酵素活 性在保持し，糖代謝扔上びエネルギー代謝の改善に奇与 する作用をむつもの上考えられる。

デキサメサゾンは一般的に脳浮腫に対して, 毛細血管 壁や基底膜，膠細胞の変化を抑制し血液脳関門を安定さ ษ，また，星状廖細胞のミトコンドリアを增加し，高い エネルギーを産生させる效果があるとされる醇素で は, LDH の増加がみられ，嫌気性解糖采酵素の活性增 加をもたらすをの機序は不明であるが，酵秦合成を促 ᄂ，代謝改善を行お弓と寸る合目的的な効果をもつもの と考えられるが，今回の圧迫による硬塞発現には効果を 示さなかった

DMSO 《血流増加，呼吸量の増加，利尿作用やライ

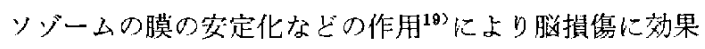

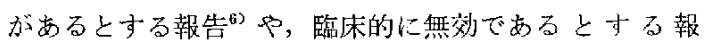
告 ${ }^{23}$ 女あり意見の分か机るところであるが，压迫脳にお いては酵素組織化学的に主剂果を示さなからた。

\section{V 結 語}

1. 圧迫による実験的媨損甥を作製し，玨迫力の程度 および 2,30 影響因子が司所の这組織に与える変化に ついて，病理組織学扢よび醉素組織化学的に光顁により 検討した。

2. 圧迫力が強くなるに従い脳浮腫, 静脈性硬塞, 出 血性硬塞が生じる.

3. 橋静脈切断により静脈還流障害を生ぜしめた脳に 压迫を加えると，硬塞性出血により血腫が形成され脑損 賃が高度になることから，脳手術において静脈の切断は 可能な限り避けるべきであることを強調した。

クモ膜下出血注圧迫脎に対し著明な変化江認めなかっ た.

4. 酵素組織化学的には特に膠細胞の嫌気的解糖系醉
素の活性増加と, 星状膠和胞と毛細血管壁の酵素活性変 化がみられ，嫌気的解糖系の元進と血液鼡関門の障害が 示唆された。

5. デキサメサゾン，グリセロール执よび DMSO 投 与が圧迫媨に与える影響について険討したところ，病理 組織学的には著変学認めず，酵素組織化学的にはグリ七 ロールとデキサメサゾンが酵素活性に変化を与え，脳組 織に対しェネルギー供給に促進的に働く可能性が示唆さ れた。

本槁至終えるに際し，御指導と御協力を賜った佩研成 肉部門 高至豪營教授に感謝いたします。

な就本諭文の要旨は，第38四日本畄神経外科学会総会 に扔いて発表した。

\section{文献}

1) Albin, M.S., Bunegin, L., Dujorny, M., et al.: Brain retraction pressure during intracranial procedures. Surg Forum 26: 499-500, 1975

2) Bourne, G. H.: Histochemical demonstration of phosphatases in the central nervous system of the rat. Exp Cell Res 5: 110-117, 1958

3) Burstone, M. S.: New histochemical techniques for the demonstration of tissue oxidase (cytochrome oxidase). $J$ Histochem Cytochem 7 : 112-122, 1959

4) Burstone, M. S.: Enzyme histochemistry and its application in the study of neoplasm. Academ. ic Press New York and London, 1962

5) Cumings, J. N.: Water soluble proteins and enzymes in normal and in edematous brain tissue. In Proceedings of Fourth International Congress of Neuropathology, Stuttgart George Thieme Verlag, 1962, pp 157

6) Dela Torre, J. C., Rowed, D. W., KawaNAGA, H. M., et al.: Dimethylsulfoxide in the treatment of experimental brain compression.

$J$ Neurosurg 38: 345-354, 1973

7) Geiger, A., Kawakita, Y. \& Barkulis, S. S.: Major pathyways of glucose utilization in the brain in brain perfusion on experiments in vivo and in situ. $J$ Neurochem 5: 323-338, 1960

8) Gilsanz, V., Rebollar, J. L., Buencuerpo, J., et al.: Controlled trial of glycerol versus dexamethazone in the treatment of ccrebral edema in acute cerebral infarction. Lancet 7915: $1049-1051,1975$

9) Goodman, S. J. \& Becker, D. P.: Vascular pathology of the brain stem due to experimentally increased intracranial pressure: Changes noted in the micro-and macrocirculation. $J$ 
Neurosurg 39: 601-609, 1973

10) Hassler, D.: Deep cerebral venous system in man. Neurology 16:505-511, 1966

11) Hatanaka, M., Kodama, N., Sakurai, Y. et al.: Aneurysm surgery in the older patients. Neurol Surg 7: 229-232, 1979

12) Hess, H. H.: Regional neurochemistry. PP 200-212, In Kety, S. S. \& Klkes, J.(eds): Pergamon Press, Oxford, 1961

13) Huang, Y. P. \& Wolf, B. S.: Veins of the white mater of the cerebral hemispheres (the medullary veins). Am $J$ Roeniogen 92: 739, 1964

14) Ishit, S., Haynor, R., Kelly, W. A., el al.: Studies of cerebral swelling. II Experimental cerebral swelling produced by supratentorial extradural compression. $J$ Neurosurg 16:152-166. 1959

15) Ito, T., Allen, N. \& Yashon, D.: A mitochondrial lesion in experimental spinal cord trauma. J Neurosurg 48: 434-442, 1978

16) K.alsbeck, J. E., Klazo, I. \& Miguel, J.: Histochemical observations on oxidative enzymes activity of glial cells in a local brain injury. $J$ Neuropathol Exp Neurol 21:116, 1962

17) Klazo, I.: The relationship between edema, blood brain barrier and tissue elements in a local brain injury. $J$ Neuropathol Exp Neurol 17: $548-564,1958$

18) KLAzo, I.: Neuropathological aspects of brain edema. $J$ Neuropathol Exp Neurol 26: 1·14, 1967

19) Kiogman, A.: Topical pharmacology and toxicology of dimethyl sulfoxide. $J$ Am Med Sci 192: 309-313, 1965

20) Krayenbühl, H. A.: Cerebral venous and sinus thrombosis. Clin Neurol 14: 1-23, 1967

21) Laurent, J. P., Molinari, G. F. \& Oakley, J. C.: Primate model of cerebral hematoma. $J$ Neuropathal Exp Neurol 35:560-568, 1976

22) Liu, H. Ch., Lee, J. C. \& Bakey, L.: Experimental cerebral concussion. Acta Neurochir (Wein) 47: 105-122, 1979

23) Long, D. M.: A new therapy regimen for brain edema. pp 293-300, In Pappius, H. M.(ed): Dynamics of brain edema. Springer Verlag, 1976

24) Lowry, O. H.: Mechanism of the nervous system. Richter, D.(ed), Pergamon Press, New York, 1957, pp 323

25) Lubinstein, L. J., Klazo, I. \& Miquel, J.: Histochemical observations on oxidative enzyme activity of glial cells in a local brain injury. $J$ Neuropathol Exp Neurol 21:116-136, 1962

26) Mathew, N. T., Meyer, J. S., Tivera, V. M., et al.: Double blind evaluation of glycerol therapy in acute cerebral infarction. Lancet 7791: 1327-1329, 1972

27) Matsunami, T.: Histochemical study of lactiv dehydrogenase in the brain. Med $J$ Osaka Univ 11:3617-3631, 1959

28) Mctlwain, H. \& BachelaRd, H. S.: Biochemistry and central nervous system. London Churchill livingston, 1971, pp 322

29) Meyer, J. S., Charney, J. Z., Rivera, V. M., et al.: Treatment with glycerol of cerebral edema due to acute cerebral infarction. Lancet 7732: 993-997, 1971

30) Meyer, J. S., Ito, Y., Окамотo, S., et al.: Circulatory and metabolic effects of glycerol infusion in patients with recent ccrebral infarction. Circulation 51: 701-712, 1965

31) OKada, K.: An electron microscope study on the brair edema, with reference to the effect of hypertonic solution and steroid hormone. Brain Neru (Tokyo) 17: 1025-1039, 1965

32) Ostereerg, K. A. \& Wattenberg, L. W.: Oxidative histochemistry of reactive astrocytes. Arch Neurol 7: 211-218, 1962

33) Putnum, T. J.: Studies in multiple sclerosis: Encephalitis and sclerotic plaques produced by vascular obstruction. Arch Neurol Psychiatr 33: 929-940, 1935

34) REID, W. L. \& Cone, W. V.: The mechanism of fixed dilatation of the pupil resulting from ipsilateral cerebral compression. J Am Med Assoc 112: 2030-2034, 1939

35) Robinson, N.: Histochemical change in neocortex and corpus callosum after intracranial injection. $J$ Neurol Neurosurg Psychiatry 32: 317323,1969

36) Robinson, N. : Enzyme response of traumatized tissue after intracortical injection into 5 day old rat brain. J Neurol Neurosurg Psychiaty 35: 865872, 1972

37) Romaul, F. C. A.: Selective infarction of gray or white matcr caused by occlusion of large arteries. Clin Dev Med 39/40:41-46, 1971

38) SCHLestnger, B.: The venous drainage of the brain, with special reference to the Galenic system. Brain 62: 274, 1939

39) Speri, M. P., Svien, H. J., Goldstein, N. P., et al.: Experimental production of local cerebral cdema by an expanding intracerebral mass. Staff Meeting of the Mayo Clinic 32: 744-749, 1957

40) Stenaevs, W. E.: Pathology of the cerebral blood vessels. C.V. Mosby, 1972, pp 131-206

41) Symov, L.: Disordered cerebro-vascular physiology in aneurysmal subarachnoid hemorrhage. Acta Neurochir $41: 7-22,1978$

42) Takeuchi, T. \& Kuriaki, H.: Histochemical detection of phosphorylase in animal tissues. $J$ Histochem Cytochem 3: 153-160, 1955

43) Torack, R. M., Besen, M. \& Becker, N. H.: Localization of adenosine-triphosphatase in 
capilaries of the brain as revcaled by electron microscopy. Neurology 11: 71-76, 1962

44) Tsukada, U.: Biochemistry of the brain. Igaku Shoin, 1964, pp 85-115

45) Virno, M., Chtavarelit, S. \& Cantore, G. P.: Azone del glicerolo sull' edema cerebrale ncl coniglio dopo craniectomia. Gazz Int Med Chir 66: 3509-3515, 1961

46) Wachestein, M. \& Meisel, E.: Histochemistry of hepatic phosphorylases at a physiologic pH. Am J Clin Pathol 27: 13-23, 1957

47) Yanagihara, T., Goldstein, N. P., Svien,
H. J., et al.: Enzyme histochemical study of experimental cerebral edema. Trans Am Neurol 90: 130-140, 1965

48) Yanaghara, T., Goldstein, N. P., Svien, H. J., et al.: Experimental cerebral edeman, enzyme-histochemical study. Neurology 17:669 679,1967

49) ZüLch, K. J.: In Pathology of Nervous System. Minckler(ed), McGrawhill, 1971, pp 1499-1548

50) ZüLch, K. J.: Neuropathology of intracranial hemorrhage. Prog Brain Res 30: 151-165, 1968 